JURNAL ILMU PEMERINTAHAN:

Kajian Ilmu Pemerintahan dan Politik Daerah

Volume 4- Nomor 1, April 2019, (Hlm 47-63)

Submission: 03-03-2019; Revision: 10-05-2019; Published: 15-05-2019

Available online at: http://e-journal.upstegal.ac.id/index.php/jip

Doi: http://dx.doi.org/10.24905/jip.v4i1.1212

\title{
Analisis Politik Milenial : Persepsi Siswa SMA Terhadap Dinamika Politik Pada PEMILU 2019 di Indonesia
}

\author{
Mulkanur Rohim ${ }^{*}$ ), Amika Wardana ${ }^{2)}$ \\ 1,2 Program Pascasarjana Pendidikan IPS, Universitas Negeri Yogyakarta. Jl. Colombo No.1, \\ Daerah Istimewa Yogyakarta 55281 Indonesia \\ *Korespondesi email: aanngawi48@gmail.com,
}

\begin{abstract}
Abstrak
Generasi milenial pada analisis politik, memiliki empat sumber dalam membentuk persepsi politiknya yaitu media sosial, keluarga, teman dan sekolah. Milenial direpresentasikan pada siswa SMA dengan sampel Siswa SMA di Yogyakarta. Penelitian ini menggunakan metode kualitatif dengan pendekatan grounded theory. Hasilnya pembahasan isu politik dilakukan dengan diskusi, perdebatan dan akses informasi. Dari isu politik tersebut membentuk persepsi pada individu yang melalui tahapan seleksi, interpretasi dan berakhir pada Pembulatan. Namun persepsi yang terbentuk bukan terpaku pada isu politik yang dibahas tetapi lebih pada sosialisasi yang sudah diterima individu sebelumnya. Oleh karena itu media sosial sebagai sumber informasi utama sekarang ini hanyalah sebagai penegas pada persepsi yang sudah terbentuk atau sebagai pembahasan kontradiksi pada persepsi yang sudah terbentuk.
\end{abstract}

Kata kunci : Politik Milenial; Pemilu; Indonesia

\section{Analysis of Milenial Politics: Perception of High School Students Against Political Dynamics in 2019 Election in Indonesia}

\begin{abstract}
Millennials in the political analysis have four sources in shaping their political perceptions, namely social media, family, friends, and school. Millennials are represented in high school students with a sample of high school students in Yogyakarta. This study uses a qualitative method with a grounded theory approach. The result is a discussion of political issues carried out with discussion, debate, and access to information. From the political issue, it forms perceptions on individuals who go through the stages of selection, interpretation and ending in rounding. But the perceptions formed are not fixed on the political issues discussed but rather on the socialization that has been received by the individual before. Therefore social media as the main source of information today is only as a confirmation of the perceptions that have been formed or as a discussion of contradictions in perceptions that have been formed.
\end{abstract}

Keyword: Politic Millenial; Election; Indonesia 


\section{Jurnal Ilmu Pemerintahan: Kajian Ilmu Pemerintahan dan Ilmu Politik, 4 (1), April 2019- 48 \\ Mulkanur Rohim ${ }^{*}$ ), Amika Wardana ${ }^{2)}$}

\section{PENDAHULUAN}

Politik merupakan aspek di masyarakat yang dekat dengan khidupan individu. Pengertian politik itu sendiri dari Laswell (1952) menjelaskan bahwa politik merupakan suatu proses dalam bentuk "siapa yang mendapatkan apa, kapan dan bagaimana" (politics as who gets, what, when, and how). Easton (1981) merumuskan politik sebagai pola-pola kekuasaan, aturan dan kewenangan, kehidupan publik, pemerintah, dan konflik. Affandi (1971) berpendapat bahwa yang dimaksud dengan politik sebenarnya ialah usaha-usaha yang dijalankan oleh para warga negara untuk mencapai kekuasaan dalam negara. Menurut Budiarjo (2008) politik adalah bermacam-macam kegiatan dalam suatu sistem (sosial) yang menyangkut proses menentukan dan melaksanakan tujuan. Sehingga aspek politik selalu terkait dengan pendidikan politik.

Pendidikan politik menjadi isu yang penting dibahas saat ini, karena dalam menumbuhkan dan mengembangkan kesadaran politik harus dimulai pada generasi yang lebih muda. Mematangkan pemahaman terhadap orientasi politik secara fundamental dan komprehensif menjadi pekerjaan berat dalam perkembangan demokrasi di Indonesia. Sirozi (2005: 49) menyatakan bahwa salah satu kondisi fundamental untuk mempertahankan suatu sistem politik bahwa ketika generasi muda dalam suatu masyarakat, mereka harus menguasai ilmu pengetahuan, nilai-nilai, dan sikap-sikap sebagaimana diharapkan oleh para anggota dan sistem yang ada. Pendidikan politik yang diterima dari keluarga, sekolah, media massa, dan media sosial menjadikan pemahaman yang berbeda dalam setiap individu.

Permasalahannya menurut UndangUndang Republik Indonesia Nomor 2 Tahun 2018 tentang Partai Politik menyatakan bahwa Pendidikan Politik merupakan salah satu fungsi dari partai politik, dan negara, dalam hal ini pemerintah tidak melibatkan diri untuk melakukan Pendidikan Politik. Hal ini diperkuat dengan Peraturan Menteri Dalam Negeri Nomor 36 Tahun 2010 tentang Pedoman Fasilitasi Penyelenggaraan Pendidikan Politik dimana negara hanya bersifat memfasilitasi program-program Pendidikan Politik yang dilakukan para agen politik (Winarno, 2014: 8-9).

Pendidikan politik yang belum masif membuat minimnya tingkat kepercayaan masyarakat terhadap sistem politik yang ada, sudah saatnya masyarakat dibekali dengan Pendidikan Politik, khususnya bagi pelajar. Tujuannya memberikan dan menganalkan pengetahuan politik, kesadaran politik, nilai, sikap dan orientasi politik, dan mampu berpartisiasi dalam politik (Zamroni, 2000: 25). Pemilih pemula pada generasi muda khususnya pelajar lebih cepat dalam menerima informasi dari media sosial. sumber media sosial tersebut tidak seutuhnya dapat dipercaya sehingga dapat memberikan perdebatan.

Ledakan informasi di media mengenai Pemilu 2019 akan berdampak pada pendapat dan pemahaman calon pemilih utamanya pemilih pemula. Pasalnya, media kini menjadi alat bagi partai politik untuk menggiring opini publik mendukung partainya. Hal ini dikarenakan, remaja ini cenderung mengalami masa keadaan emosi yang labil, sehingga dapat menyebabkan remaja sulit mendapatkan informasi yang dibutuhkan dengan tepat. Remaja tentu memiliki persepsi, pemikiran, kemauan, dan keyakinan terhadap Pemilu (Sukendar,2017:75).

Media berbasis digital merupakan media baru yang membuat informasi yang secara masif dapat tersampaikan secara cepat dan interaktif. Banyak pengerak politik praktis menggunakan dan memanfaatkan media sosial sebagai alat kampanye politik, kelebihannya dapat menjangkau pemilih pemula dengan modal yang sedikit. Era interaktif digital, produksi pesan dan citra politik menjadi hal yang rawan. Pelaku politik harus mempertimbangkan kemungkinan bahwa pesan-pesan mereka akan dimodifikasi 


\section{Jurnal Ilmu Pemerintahan: Kajian Ilmu Pemerintahan dan Ilmu Politik, 4 (1), April 2019- 49 \\ Mulkanur Rohim ${ }^{*}$ ), Amika Wardana ${ }^{2)}$}

oleh pihak lain ketika pesan tersebut disampaikan melalui media sosial. Lingkungan media digital tidak menghargai integritas informasi, ketika informasi itu sudah dipublikasikan secara online, maka siapa pun bebas untuk memodifikasinya (Gurevitch, et.al, 2009). Branding pada media sosial digerakan secara aktual dan dikelola secara terus-menerus untuk menjaga konsistensi komunikasi dengan topik yang berkembang di lingkungan masyarakat. Menjaga eksistensi informasi dalam media sosial dipengaruhi oleh pengelolaan media secara berkelanjutan

Politik merupakan pembentukan dan pembagian keputusan dalam masyarakat untuk pengambilan keputusan dalam negara. Bagaimana negara tersebut dapat berjalan dengan baik melalui aturan negara-aturan negara yang terorganisir. Konsensus dari negara demokrasi telah memastikan terselenggaranta pemilihan umum (pemilu) sebagai indikator yang mutlah harus dijalankan (Rahmawati, 2018). Azmi (2016) memperkuat bahwa pemilihan umum merupakan salah satu pilar dan poin penting dalam sebuah negara demokrasi. Pemilihan umum (pemilu) merupakan sarana perwujudan kedaulatan rakyat yang diselenggarakan secara langsung, bebas, rahasia, jujur dan adil guna menghasilkan pemerintahan negara yang demokratis berdasarkan pancasila dan Undang-undang Dasar Negara Republik Indonesia tahun 1945. Indonesia adalah negara yang yang sudah menjadi bagian integral historis pelaksanaan sistem ketatanegaraan. Pada tahun 1995 Indoensia sudah melangsungkan pemilu pertama yang demokratis. Kemudian berlanjut pada era orde baru tahun 1971, 1977, 1882, 1987, 1992, 1997. Selanjutnya pada masa reformasi telah berlangsung tiga kali pemilu yakni tahun 1999, 2004, dan 2009. Berjalannya pemilihan umum tersebut, maka istilah pemilu telah familiar bagi penduduk Indonesia sebagai hak politik rakyat Indonesia.
Penduduk Indonesia terdiri dari berbagai suku, agama, budaya, dan generasi yang memiliki hak dalam pemilihan dalam pemilu, sehingga setiap individu didalam

\section{Radio}

= Milenial (17-29 tahun) $\quad$ Non Milenial (Di atas 30 tahun)
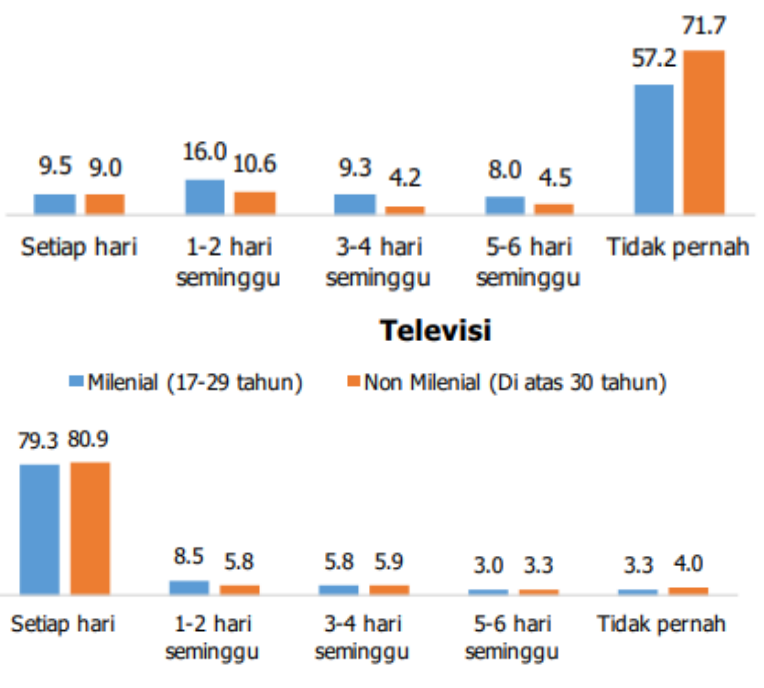

Surat kabar

milenial (17-29 tahun) $\quad$ Non Milenial (Di atas 30 tahun)

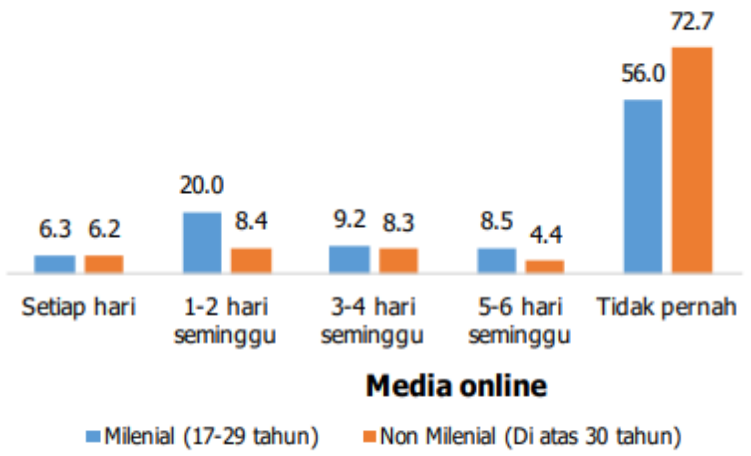

76.

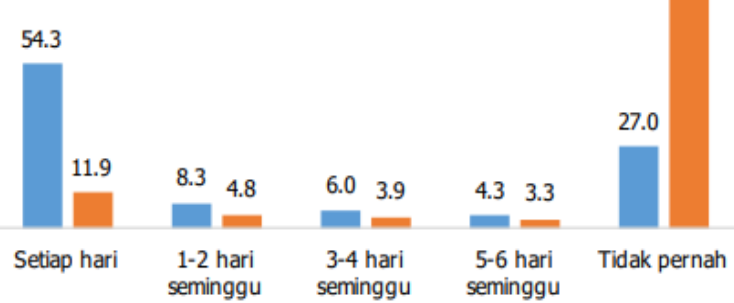

Gambar 1. Grafik Penetrasi Milenial

Sumber. Survei CSIS 2017

masyarakat Indonesia mempunyai peranan dalam pemilu. Menurut Perangin (2018) mencatat jumlah non-voter (biasa disebut golongan putih atau golput) yang terutama didominasi oleh pemilih muda, terus meningkat dari pemilu ke pemilu berikutnya; $10,21 \%$ pada pemilu 1999, meningkat 


\section{Jurnal Ilmu Pemerintahan: Kajian Ilmu Pemerintahan dan Ilmu Politik, 4 (1), April 2019-50 \\ Mulkanur Rohim ${ }^{*}$ ), Amika Wardana ${ }^{2)}$}

menjadi $23,345 \%$ pada pemilu 2004, dan $39,10 \%$ pada pemilu 2009.

Pembahasan politik sekarang menjadi hidangan pembuka seperti "french fries" bagi semua kalangan umur, pembahasan yang menarik dalam setiap dinamikanya. Permasalah mengenai politik selalu menjadi headline di media massa dan media sosial terutama menjelang PEMILU 2019 di Indonesia. Terutama bagi kaum milenial dan pemilih pemula yaitu pelajar siswa SMA yang sudah memasuki tahun pertama mengikuti PEMILU. Komunikasi politik sekarang yang disasar oleh para calon menggunakan media sosial, oleh karena itu komunikasi politik penting dilakukan sebagai strategi untuk mendapatkan sebuah dukungan dan pemenuhan kebutuhan dalam sistem politik, dengan asumsi dapat memenuhi kepentingan, serta mengambil keuntungan melalui kebijakan dan strategi politik (Mulyana, 2013).

Pada pemilihan presiden berdasarkan hasil survey Lembaga Survey Nasional, perilaku memilih (voting behaviour) pemilih pemula berbeda dari masyarakat pada umumnya, survey tersebut menunjukan mayoritas pemilih pemula 46,4 \% mengutamakan kemampuan calon presiden dalam memecahkan masalah, 41,3 \% pemilih pemula tidak mempermasalahkan latar belakang suku calon presiden, 3,6 \% mengaku meminta pendapat dan saran dari orang lain, dan sisanya hanya 1,8 \% mengaku akan mengikuti pilihan orang yang disegani. Dari hasil survey tersebut dapat disimpulkan bahwa pemilih pemula termasuk dalam kategori penekatan rasional (Azmi, 2016).

Milenial merupakan salah satu lumbung suara untuk kontestasi politik sehingga pendekatan media sosial adalah cara paling efektif untuk dapat memperkenalkan diri dalam gagasan maupun pengenalan personal oleh calon yang akan berkontestasi. Survey Nasional CSIS tahun 2017 menampilkan data tentang penetrasi milenial sebagai berikut:
Selain itu data CSIS tahun 2017 menunjukan pilihan kaum milenial terhadap calon presidennya adalah sebagai berikut:

Tabel 1. Pilihan Presiden Berdasarkan Akun Media Sosial

\begin{tabular}{lcccc}
\hline Kategori & FB & Twitter & Path & IG \\
Baseline & 81.7 & 23.7 & 16.2 & 54.7 \\
Jokowi & 30.6 & 22.5 & 21.6 & 26.5 \\
Prabowo & 28.6 & 24.6 & 25.8 & 29.6 \\
Lainnya & 37.6 & 48.6 & 50.5 & 39.9 \\
TT/TJ & 3.3 & 4.2 & 2.1 & 4.0 \\
Total & 100 & 100 & 100 & 100
\end{tabular}

Sumber. Survei CSIS 2017 (\%)

Data diatas dapat diambil kesimpulan bahwa pendekatan media sosial sekarang ini menjadi salah satu fokus dalam dunia politik untuk dikembangkan. Pengenalan dengan media sosial akan membentuk persepsi dimana informasi yang diterima akan dicerna untuk dijadikan bahan pertimbangan dalam pemilihan dalam PEMILU. Oleh karena itu pendekatan teori komunikasi hermeneutika menjelaskan bahwa persepsi menjadi pendukung bagi perasaan akan adanya pemahaman dengan cara membuka saluran komunikasi. (Sobur, 2013 :278). Proses terbentuknya persepsi dalam buku Filsafat Komunikasi dijelaskan terdapat tiga komponen yaitu: a) Seleksi, b) Interpretasi, c) Pembulatan. Ketiga komponen tersebut bekerja ketika informasi politik yang diterima sehingga membentuk pandangan positif maupun negatif terhadap informasi politik yang diterima.

Persepsi merupakan suatu proses yang didahului oleh proses pengindraan, yaitu proses diterimanya stimulus oleh individu melalui alat indra atau juga disebut proses sensoris. Namun proses itu tidak berhasil begitu saja, malainkan stimulus tersebut diteruskan. Karena itu proses persepsi tidak dapat dari proses pengindraan, dan pengindraan merupakan proses pendahuluan dari proses persepsi (Bimo Walgito, 2002:8788). Pendapat lain dikemukakan oleh Learner dalam Mulyono Abdurahman (2003: 151) 


\section{Jurnal Ilmu Pemerintahan: Kajian Ilmu Pemerintahan dan Ilmu Politik, 4 (1), April 2019- 51 \\ Mulkanur Rohim ${ }^{*}$ ), Amika Wardana ${ }^{2)}$}

yang mendefinisikan persepsi adalah batasan yang digunakan pada proses memahami dan mengintepretasikan informasi sensoris atau kemampuan intelek untuk merencanakan makna dari data yang diterima dari berbagai indra. Dari pendapat para ahli di atas dapat disimpulkan, persepsi merupakan proses perlakuan seseorang terhadap objek atau informasi yang diterima melalui pengamatan dengan menggunakan indra yang dimiliki. Proses persepsi ini berkaitan dengan pemberian arti atau makna serta mengintepretasikan objek yang diamati. Persepsi siswa merupakan proses perlakuan siswa terhadap informasi tentang politik melalui pengamatan dengan indra yang dimiliki, sehingga siswa dapat memberi arti serta mengintepretasikan hal tersebut.

Namun proses yang terjadi dimasyarakat terutama pada kaum milenial terhadap persepsi tidak sederhana, karena latar belakang seorang individu dan pengalaman pribadi serta kondisi lingkungan sosial budaya memaksa seseorang untuk berpersepsi sesuai keadaan lingkungan sekitar yang membentuknya. Ditambah dengan adanya konsep post-truth bahwa fakta tidak terlalu berpengaruh dalam membentuk opini publik dibanding dengan emosi dan keyakinan personal dimana seoarang individu hanya membaca dan menerima berita terkait politik hanya pada berita yang disukai atau berita yang dapat membuat nyaman dalam kehidupannya. Terlepas dari kebenaran kontektualisasi yang ada dalam berita tersebut terutama dalam dunia politik. (lihat Syuhada, 2017)

Sejalan dengan era post truth ini dalam jurnal Komunikasi Indonesia (2017) yang berjudul Etika Media di Era Post Truth menyampaikan sebuah isu menyangkut media bahwa dunia sekarang pada masa yang mengkhawatirkan dengan sirkulasi peredaran berita yang dipelintir dan informasi palsu yang beredar melalui media sosial terutama dalam sorotan ini adalah facebook dimana perusahaan ini mendapatkan untung besar karena persebaran berita negatif yang ada di lini masa facebook. Meskipun demikian hampir semua media sosial mengalami hal yang sama bahwa berita bohong atau hoax semakin menyebar dalam lingkungan media sosial. ( Syuhada, 2017)

Penelitian mengenai persepsi masyarakat sudah banyak dilakukan seperti penelitian Handrix C H dari Universitas Paramadina dalam Jurnal Psikologi Tahun 2015, Zainal dari Universitas Lambung Mangkurat dalam Jurnal Pendidikan Kewarganegaraan Tahun 2015. Hasil dari penelitian tersebut beragam sesuai dengan tempat dan waktu dilaksanakan dan relatif masyarakat memiliki pandangan positif dan negatif dalam dinamika politik di Indonesia. Tetapi pembahasan ini akan berfokus pada persepsi siswa terhadap dinamika politik di Indonesia, meskipun akan dipakai irisan dari paradigma post-truth untuk membahas kaum milenial terhadap media sosial. Arah penelitian pada analisis politik pada kaum milenial dengan pendekatan persepsi.

\section{METODE}

Penelitian ini menggunakan pendekatan kualitatif deskriptif. Penelitian kualitatif deskriptif menghasilkan data deskrpitif berupa gambaran kata-kata yang berdasarka pada fakta yang ada di dalam fenomena sosial Penelitian ini menggunakan metode kualitatif karena peneliti menganggap pemilih pemula sebagai kaum milineal merupakan fenomena sosial yang yang ada dalam kontestasi pemilu sehingga banyak diantaranya dalam fase pembentukan sosialisasi oleh lingkungan sekitar.

Penelitian ini dilakukan pada bulan November 2018, bertempat di beberapa Sekolah Menengah Atas di Yogyakarta. Mengambil SMA Negeri dan SMA Swasta yang berada di Yogyakarta. Penelitian ini dilakukan pada siswa SMA kelas dua belas, dikarenakan mereka adalah kaum milenial dan untuk pertama kalinya menjadi pemilih pemula pada 


\section{Jurnal Ilmu Pemerintahan: Kajian Ilmu Pemerintahan dan Ilmu Politik, 4 (1), April 2019- 52 \\ Mulkanur Rohim ${ }^{*}$ ), Amika Wardana ${ }^{2)}$}

PEMILU 2019. Dalam pemilihan informan dilakukan secara purposive sampling terhadap karakteristik pemilih pemula yang sesuai oleh amanat Undang-undang. Penelitian ini mengambil siswa-siswa SMA di Yogyakarta agar sampel dapat merepresentasikan siswa SMA sebagai kaum milenial dan pemilih pemula.

Penelitian ini secara langsung mengambil data primer, dengan teknik pengumpulan data secara observasi dan wawancara. Sumber data dari penelitian ini dipilih secara random pada sekolah di Yogyakarta berdasarkan klasifikasi kelas dua belas Sekolah Menegah Atas tetapai memenuhi kualifikasi umur sebagai pemilih pemula. Penelitian kualitatif ini menggunakan analisis pendekatan Grounded Theory, sebuah pendekatan yang mengembangkan teori dari data yang dianalisis secara sistematis. Grounded Theory menurut Kathy Charmaz adalah a research method that prescribes systematic guidelines for data collection and analysis with the purpose of inductively building a framework explaining the collected data (Charmaz, 2000). Analisis dengan pendekatan grounded theory merupakan kumpulan prosedur yang sistematis dan mengembangkan pemikiran berlandaskan induktif, tujuan utama dari grounded theory adalah menjelaskan fenomena dengan mengidentifikasi, mengkategori hubungan dan proses dalam penelitian. Roadmap penelitian adalah sebagai berikut:

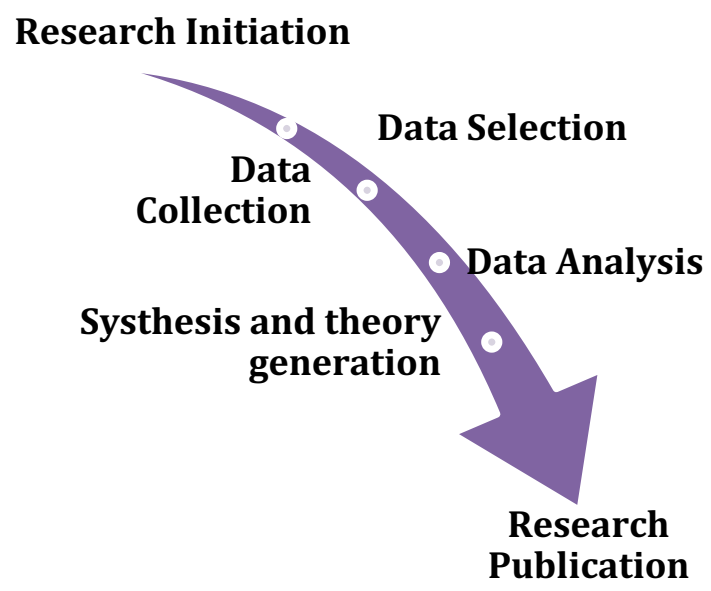

Gambar. 2 Skema Pendekatan Grounded Theori Refleksif (Dey, 1999)

\section{HASIL DAN PEMBAHASAN}

Terdapat empat narasi yang bisa dijelaskan dalam penelitian tentang persepsi siswa SMA terhadap dinamika politik pada PEMILU 2019 di Indonesia yaitu Isu Politik, Sumber Informasi Politik, Persepsi yang terbentuk dan, Stigma Politik. Informan yang diperoleh memiliki latar belakang yang berbeda, sehingga orientasi terhadap politik memiliki substansi yang berbeda. Keterbatasan akses juga menjadi hambatan dalam memperoleh informasi politik yang seharusnya mereka dapatkan. Namun persepsi politik karena minat tetap menumbuhkan mereka untuk dapat menunjukan eksistensinya. Motivasi akan lingkungan yang menjadi peran penting dalam informan merefleksikan dirinya dalam politik.

Keaktifan informan bukan hanya didalam sekolah untuk membahas politik tetapi juga di media sosial bahkan juga ikut serta dalam kegiatan politik praksis diluar jam sekolah. Keterbatasan waktu karena padatnya ekstrakurikuler menjadi kendala informan dalam mengakses media sosial guna lebih aktif dalam kegiatan politik. Meskipun begitu informasi yang mereka peroleh tidak menunjukan adanya alienasi informasi yang didapatkan.

\section{Isu Politik sebagai Pesan Komunikasi}

Terdapat pola dalam komunikasi informan dalam membahas isu politik, pola tersebut mengulang secara relatif dalam keseharian komunikasi informan. Pola tersebut mempunyai tiga unsur yaitu: informasi politik, diskusi politik dan perdebatan politik. Pola dari komunikasi dalam membahas isu politik digambarkan oleh bagan sebagai berikut: 


\section{Jurnal Ilmu Pemerintahan: Kajian Ilmu Pemerintahan dan Ilmu Politik, 4 (1), April 2019- 53 \\ Mulkanur Rohim $^{1 *}$, Amika Wardana ${ }^{2)}$}

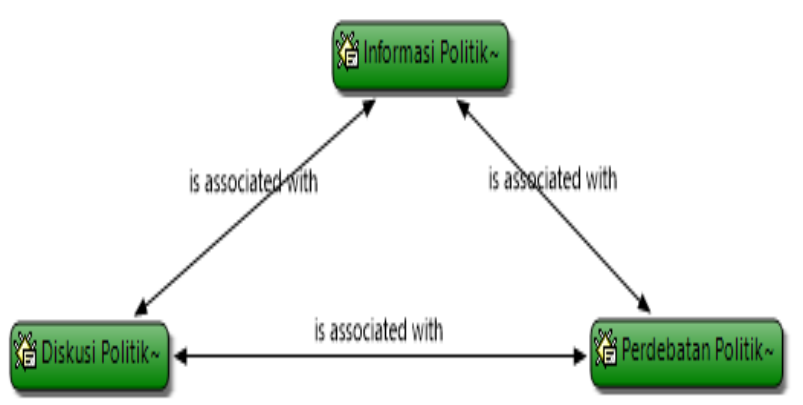

Gambar 3. Pola Komunikasi

Dalam pola tersebut mereka memulai komunikasi bukan hanya ketika mendapatkan informasi, tetapi secara random mereka bisa mendapatkan isu politik dari diskusi, perdebatan atau infomasi secara langsung. Hal ini sesuai pada pernyataan informan FI yang menjelaskan bahwa setelah mendapatkan informasi isu politik di internet atau dikoran mereka mengajak beberapa teman untuk membicarakan hal tersebut kepada teman yang paham dan tertarik kepada isu politik, agar komunikasinya dinamis dan bisa bertukar pendapat. (Wawancara November 2018)

Isu politik biasanya dibicarakan melalui media mainstream seperti koran, berita televisi dan akhirnya secara kongkrit dibicarakan oleh siapa saja pada lapisan masyarakat terlebih menjalang PEMILU pada dasarnya komuniikasi tersebut merupakan komunikasi politik dimana pertukaran informasi antara elite penguasa kepada warga negara melalui media dengan simbol-simbol politik yang telah diproses kepada ruang publik untuk memberikan efek potensial dan aktual pada fungsi sistem politiknya. ( lihat Sumartias, 2017)

Proses komunikasi politik merupakan tahapan pesan politik untuk memperoleh feedback, dimana siswa yang memperoleh isuisu politik mencoba menyampaikan pesan kepada temannya sehingga mendapatkan tanggapan dengan apa yang sudah disampaikannya, pada proses ini bentuk dalam proses komunikasi mencakup beberapa tahapan seperti konsep dari Burhan Bungin (2007: 255-256) yaitu: pertama,
Ideation dimana proses penciptaan gagasan pada seperangkat informasi yang dikomunikasikan, tahapan ini merupakan landasan siswa untuk menyapaikan pesan berupa isu-isu politik untuk disampaikan. Informan dalam penelitian ini sebagai komunikator menciptakan pesan bedasarkan ide dari media online, televisi dan orang tua untuk mempengaruhi isi pesan dalam komunikasinya. Kedua, Encoding dimana komunikator menerjemahkan informasi dalam wujud verbal maupaun non verbal sehingga memberikan efek terhadap orang lain, Siswa SMA di Yogyakarta menggunakan bahasa dan simbol seperti: tagar "Gaspol" atau tagar "2019gantipresiden" dalam pilihan politik mereka untuk menunjukan bahwa mereka mempunyai sikap tegas terhadap pilihan politik. Hal ini mensimbolkan komunikasi mereka menggunakan lambanglambang atau slogan dalam pesan komunikasi mereka. Ketiga, proses penyampaian sandi tersebut menggunakan saluran-saluran yang terkini. Misalnya dalam kasus anak SMA di Yogyakarta mereka menggunakan saluran seperti whatsapp dan Instagram untuk mencari eksistensi pilihan politik pada pesan mereka. Keempat, mengalihkan perhatian kepada penerima pesan sehingga penerima pesan melakukan decoding artinya penafsiran interpretasi pesan yang sampai kepadanya. Dalam proses ini pemahaman menjadi kunci terlebih pembahasannya adalah politik dimana sesitivitas menjadi salah satu faktor dalam proses komunikasi. Kelima, tahapan terakhir adalah feedback sehingga memungkinkan pemberian respon dengan pertimbangan yang memungkinkan dari komunikator kepada komunikan. Pesanpesan politik yang menjadi pembahasan siswa SMA di Yogyakarta adalah dinamika politik yang lebih cenderung pada pembahasan PILPRES sehingga terjadi diskusi pada tahapan mereka.

\section{Komunitas dan Sumber Informasi Politik}




\section{Jurnal Ilmu Pemerintahan: Kajian Ilmu Pemerintahan dan Ilmu Politik, 4 (1), April 2019- 54 \\ Mulkanur Rohim $^{1 *}$, Amika Wardana ${ }^{2)}$}

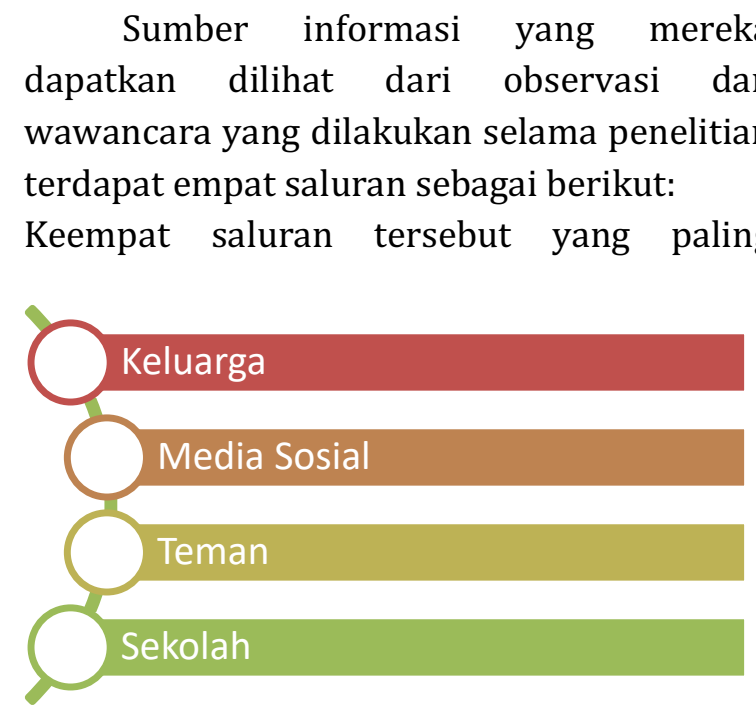

fundamental untuk melandasinya adalah orang tua, karena sosialisasi yang informan dapatkan paling lama dan tertanam dalam individu informan. Peran keluarga menumbuhkan kesadaran politik dalam kehidupan politik, pada informan siswa SMA di Yogyakarta dominasi orang tua memberikan arahan tentang unsur-unsur politik yang akan dibawa anak-anaknya. Mas'oed (2008:47) menjelaskan bahwa pengalaman berpartisipiasi keluarga dalam pembuatan keputusan dapat meningkatkan kecakapan dalam kompetensi politik, interaksi politik serta berpartisipasi dalam sistem politik ketika sudah dewasa. Semua sosialisasi keluarga yang dijalankan dalam pembahsan politik memberikan dampak pada pendidikan politik, Kantaprawira (2004:55) menjelaskan bahwa pendidikan politik meningkatkan pengetahuan siswa untuk berpartisipasi secara maksimal dalam sistem politiknya

Sementara posisi media sosial adalah sumber informasi yang paling efektif untuk mendapatkan informasi secara aktual dan lebih global. Sesuai dengan pernyataan informan bahwa media sosial digunakan mencari isu politik yang sedang dibahas. Karena media sosial adalah media paling cepat dalam menyampaikan informasi. Tetapi membiasakan membaca berita dimedia sosial tidak hanya satu sumber dan mencari sumbersumber lain. Karena penyebaran berita hoax di media sosial sangat masif. (Wawancara November 2018)

Media sosial mempengaruhi dalam komunikasi politik, media sosial mempunyai peran efektif dalam kampanye terutama menjelang PEMILU (lihat Chavez 2012) media sosial menggambarkan sarana ideal dalam komunikasi untuk mengetahui informasi, opini publik, posisi politik dan membangun komunitas untuk kampanye politik. Keberhasilan media sosial dapat dilihat dari kesuksesan Barrack Obama menjadi presiden Amerika sekitar 30\% disampaikan melalui media-media baru (Riaz, 2010).

Para tokoh politik di Indonesia sekarang ini menjadikan media sosial sebagai alat kampanye pada PEMILU 2019, terlihat akun Instagram, Youtube, facebook dipenuhi dengan kegiatan mereka, kampanye tersebut baik berupa tersirat maupun tersurat. Hal ini di manfaatkan para pemilih pemula seperti anak SMA untuk mencari tahu sosok yang akan dipilihnya, pendekatan-pendekatan milineal dijadikan cara para kontestan politik untuk mendapatkan suara pemilih pemula yang mayoritas adalah siswa-siwa SMA. Iklaniklan yang viral dijadikan momentum dalam penyampaian citra diri maupun menampilkan program-program kerjanya.

Peran teman dalam mendapatkan sumber informasi menjadi dua bagian, Pertama sebagai penegas akan informasi yang sudah didapatkan dan kedua, sebagai kontradiksi terhadap informasi yang diperoleh oleh teman dengan informasi yang diperoleh oleh informan itu sendiri. Sementara sekolah hanyalah fasilitator penunjang seperti ketersediaan koran sekolah

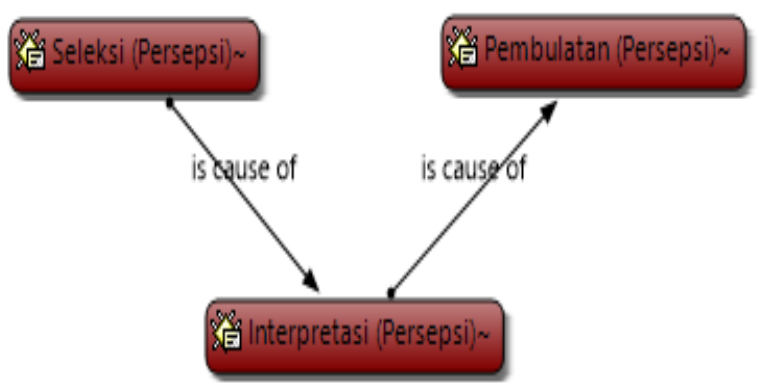




\section{Jurnal Ilmu Pemerintahan: Kajian Ilmu Pemerintahan dan Ilmu Politik, 4 (1), April 2019- 55 \\ Mulkanur Rohim ${ }^{*}$ ), Amika Wardana ${ }^{2)}$}

dan informasi dari pihak guru. Sehingga penyampaian lebih kepada normatis dan dogmatis, meskipun begitu setiap siswa sudah memiliki referensi tersendiri mengenai pilihannya tetapi tidak melakukan perdebatan dikarenakan nilai-nilai sekolah yang dijunjung oleh para siswa untuk bersikap terhadap guru dan sekolahnya.

\section{Persepsi dan preferensi Politik}

Pembentukan persepsi oleh para informan bisa dilihat dari pola dimulai dari seleksi, pembulatan dan interpretasi. Hal ini sesuai dengan tahapan persepsi dari Sobur (2013:447) yaitu seleksi adalah proses penyaringan setelah proses penyaringan tersebut masuk dalam proses pengorganisasian interpretasi ini tergantung latar belakang individu terakhir adalah pembulatan terhadap informasi yang tersampaikan. Dalam setiap informasi akan ada perbandingan yang dilakukan dari setiap informan sehingga menumbuhkan preferensi terhadap pilihan politik yang bisa mereka sesuaikan dengan individu itu sendiri.

Proses tahapan persepsi yang dilalui informan selalu mengarahkan pada pembulatan tentang pilihan politik mereka. Meskipun tanpa lugas informan menyampaikan tentang pilihan politik karena sebuah alasan agar tetap netral dilingkungan pendidikan. Persepsi siswa terbentuk karena faktor-faktor yang melekat pada individu informan, sehingga persepsi informan terhadap politik terdapat empat temuan yang spesifik sebagai berikut:

a. Persepsi siswa pengetahuan politik

Siswa SMA sudah memasuki tahap remaja yang tentunya sudah paham bagaimana dia bisa mendapatkan pengetahuan tentang isu-isu yang sedang hangat dan viral di era milenial sekarang ini. Kebutuhan informasi muncul akibat kesenjangan pengetahuan yang ada dalam diri seseorang, sehingga untuk mengatasi kesenjangan tersebut seseorang akan berusaha mencari informasi yang dibutuhkannya agar segera terpenuhi, meskipun terkadang persepsi mereka yang diperoleh masih setengah-setengah dan terkadang ada unsur subjektif sehingga dalam mengolah informasi masih sering terjadi miscommunication antara siswa yang satu dengan yang lainnya. Karena memang Pengetahuan tentang sosialisasi pemilu dari KPU belum ada, informan hanya mengetahui melalui perangkat pemilu seperti spanduk, baliho dan pamflet tentang cara memilih. Seperti yang dikatakan oleh $\mathrm{F}$ terkait dengan pengetahuan tentang politik bahwa guru terutama guru pengampu mata pelajaran PKn memberikan pemahaman politik, dan juga teman sebaya mendiskusikan pembahasan politik. Misalkan ada teman yang pulang kerumah pada saat cuti kemudian ke sekolah lagi membawa berita baru mengenai isu-isu politik dan sering menjadi diskusi masalah politik. (wawancara November 2018).

Mendiskusikan permasalahan politik sekarang ini adalah sorotan publik tentang pasangan calon presiden dan wakil presiden nomor urut 1 maupun 2 . Anggapan mereka secara anak muda setiap paslon mempunyai visi misi masing-masing sesuai dengan program kerja mereka, tetapi mereka menganggap setiap paslon pasti punya riwayat sejarah masing-masing.

b. Peran media massa / media sosial sarana memperoleh informasi

Selain memperoleh pengetahuan politik dari diskusi bersama teman-teman mereka memanfaatkan koran untuk melihat topik apa yang sedang hangat, karena di sekolah tersebut siswa tidak diperkenankan membawa handphone, kecuali sedang cuti dan pulang ke rumah. Seperti yang dikatakan oleh MRR untuk mencari informasi politik sebatas informasi dari handphone dengan mengakses youtube maupun berita online ditambah dengan media 


\section{Jurnal Ilmu Pemerintahan: Kajian Ilmu Pemerintahan dan Ilmu Politik, 4 (1), April}

2019- 56

\section{Mulkanur Rohim ${ }^{*}$ ), Amika Wardana ${ }^{2)}$}

mainstream seperti koran Republika langganan sekolah serta ditambah informasi dari guru (wawancara November 2018).

Keterbatasan mereka dalam mengakses ponsel terdapat perspektif positif karena tidak begitu banyak terkontaminasi oleh berita-berita yang terkadang membawa dampak buruk. Bahkan banyak sekali berita online yang hoax terkait isu-isu politik yang kotor dengan menghalalkan segala cara. Meskipun tidak menutup kemungkinan bahwa ponsel juga mempunyai fungsi yang lain, tetapi lebih pada penggunaan akun media sosial seperti Instagram.

c. Pengaruh dan Antusiasme tentang dunia perpolitikan

Pengaruh terhadap dunia politik dipangaruhi bukan hanya guru yang memberi gambaran tentang paslon, tetapi juga orang tua yang memberi arahan. Setiap individu mempunyai hak asasi dan bebas memilih dan menggunakan hak pilih sesuai dengan keyakinan masingmasing yang menurut mereka anggap layak menjadi pemimpin selanjutnya. Pada dasarnya semua tergantung pada pribadi masing-masing ketika sudah mempunyai Pengetahuan tentang politik, kemudian berusaha mencari dan menggali informasi kemudian segala keputusan diserahkan kembali kepada mereka yang mempunyai hak pilih. Sedangkan antusiasme mereka terlihat misalkan seperti yang dikatakan oleh $\mathrm{F}$ bahwa mengetahui apa yang sedang terjadi di Indonesia apalagi dalam hal politik itu penting, dan sebagai Pelajar kita memang harus melek tentang informasi mengenai politik di Indonesia (wawancara November 2018).

Memang ada beberapa siswa yang tertarik didunia politik terkait korupsi tapi tidak menutup kemungkinan mereka mengikuti semua berita pemilu. Antusiasmenya terlihat ketika membicarakan tentang politik dan pengetahuan politik yang banyak diketahui.

\section{Sebuah Stigma dan Pilihan}

Stigma yang muncul setelah menerima informasi terbagi menjadi dua pilihan yaitu Stigma Negatif dan Stigma Positif, kemunculan stigma ini tidak sepenuhnya terbentuk karena informasi yang didapatkan tetapi didahului pada latar belakang yang sudah tertanam dalam individu. Hal ini terkait dengan posttruth sehingga informasi yang didapatkan sifatnya hanya penegasan atau kontradiksi dalam diri informan. Hal ini seperti yang disampaikan JB bahwa bergantung doktrin mana dulu yang masuk dalam infromasi yang didapatkan siswa. Karena kalau sudah ada doktrin negatif paradigmanya akan negatif, seperti ketidakpercayaan kepada KPU (Wawancara November 2018)

Dengan adanya stigma ini bahwasannya informan bukan lagi dihadapkan pilihan apa yang benar dan terjadi tetapi lebih kepada pilihan untuk mencari atau memperoleh informasi berita yang bisa memantapkan pilihan yang sesuai dari latar belakang lnforman.

\section{Diskusi dan Pembahasan}

Kategori pemilih yang mempunyai pengaruh besar terhadap kehidupan demokrasi dimasa mendatang adalah pemilih pemula, selain jumlahnya yang terus bertambah, potensi dari daya kritis para pemlih pemula dapat menentukan hasil pemilihan. Pemilih pemula merupakan warga negara Indonesia yang didaftar oleh penyelenggara pemilihan dalam daftar pemilih dan baru mengikuti pemilu pertama kali serta terdaftar sebagai pemilih dengan rentang usia 17-21 tahun. Pemilih pemula dalam kategori politik memiliki orientasi politik yang dinamis dan akan berubah-ubah mengikuti kondisi yang ada dan faktor-faktor 


\section{Jurnal Ilmu Pemerintahan: Kajian Ilmu Pemerintahan dan Ilmu Politik, 4 (1), April 2019- 57 \\ Mulkanur Rohim ${ }^{*}$ ), Amika Wardana ${ }^{2)}$}

yang mempengaruhinya. Ciri-ciri pemilih pemula yaitu: Penduduk yang berusia 17 (tujuh belas) tahun atau sudah/pernah kawin. Baru mengikuti pemilihan (memberikan suara) pertama kali sejak pemilihan diselenggarakan di Indonesia dengan rentang usia 17-21 tahun. Mempunyai hak memilih dalam penyelenggaraan pemilihan.

Namun terlepas dari semua itu keberadaan pemilih pemula tentu menjanjikan dalam setiap pemilu, sebagai jalan untuk mengamankan posisi strategis yang ingin dicapai oleh setiap kandidat yang maju dalam pemilihan. Pada umumnya pemilih pemula belum memiliki literasi politik yang memadai, pemilih pemula cenderung mengikuti tren dilingkungan tempat tinggalnya. Kelompok pemilih pemula ini biasanya mereka yang berstatus pelajar, mahasiswa, serta pekerja muda. Pemilih pemula dalam pemilu selama ini sebagai objek dalam kegiatan politik yaitu mereka yang masih memerlukan pembinaan dan pengembangan kearah pertumbuhan potensi dan kemampuannya ke tingkat yang optimal agar dapat berperan dalam bidang politik.

Pemilih pemula atau individu yang baru mengetahui dan harus berpartisipasi menyuarakan hak nya tentu memiliki berbagai macam dugaan dan pandangan terhadap politik itu sendiri. Terlebih pemilih pemula ini dapat cepat menerima informasi dari internet yang sangat dikuasai oleh generasi ini. Berbagai macam isu politik muncul di berbagai media sosial yang dapat diakses oleh siapapun terlebih pemilih pemula yang sengaja mencari tahu bagaimana keadaan politik di Indonesia. Namun, tidak sampai disitu saja ternyata pandangan politik oleh generasi muda yang "melek" teknologi ini tidak banyak merubah paradigma. Mereka tetap memandang politik itu "kotor". Beberapa informan mengungkap politik akan bersih jika terdapat orang yang bersih, namun tetap ada informan yang berprinsip bahwa tidak ada partai politik yang bena-benar bersih. Hal ini tidak mengapa karena memang generasi muda tidak dapat diseragamkan.

PEMILU pada bulan April 2019 mendatang adalah pemilihan umum presiden, wakil presiden serta calon legislatif sebagai pesta demokrasi di Indonesia menjadi ajang dalam usaha merebut suara dari konstituennya. Tetapi sosialisasi dari KPU untuk pemilih pemula terutama bagi siswa SMA masih belum dilakukan. Masih banyak siswa yang mencari informasi sendiri. Bagi remaja, yang merupakan pemilih pemula tempat belajar politik yang pertama adalah dalam keluarga. Di dalam lingkungan keluarga mereka belajar berdemokrasi, menyampaikan pendapat, mengkritisi pendapat anggota keluarga yang lain, dan menerima hasil keputusan yang diambil dalam keluarga.

Keluarga sangat mempengaruhi cara pandang mengenai seluk beluk kehidupan yang ada di sekitarnya, termasuk pendidikan politik diperoleh pertama kali dari ruang keluarga. Keluarga mempunyai kekuatan dalam mempengaruhi secara emosional, sehingga faktor orang tua bisa membentuk perilaku pemilih mereka. Kedua adalah peran lingkungan sekolah yaitu teman sebaya atau peer group. Pengaruh teman sebaya atau sepermainan menjadi faktor yang patut dipertimbangkan, karena faktor eksternal ini bisa mempengaruhi informasi dan pendidikan politik. Teman sebaya dipercaya tidak hanya bisa mempengaruhi persepsi dan tindakan positif tetapi juga mempengaruhi persepsi dan tindakan negatif. Sehingga kecenderungan perilaku politiknya berpotensi homogen dengan perilaku politik teman dekatnya. Pengaruh guru masih dirasa batas kewajaran, hanya sedikit memberi gambaran dan mengarahkan untuk menjadi pemilih pemula yang menggunakan hak pilihnya. Ketiga, adalah Media sosial sebagai media baru dalam memposisikan diri untuk berkontribusi dalam pendidikan politik.

Media sosial bertindak sebagai komplemen dari media konvensional untuk mendukung aktivitas penggalian dana, 


\section{Jurnal Ilmu Pemerintahan: Kajian Ilmu Pemerintahan dan Ilmu Politik, 4 (1), April 2019- 58 \\ Mulkanur Rohim ${ }^{*}$ ), Amika Wardana ${ }^{2)}$}

mengidentifikasi dan memotivasi warga negara aktif serta untuk komunikasi politik internal. Dengan hadirnya media digital, khususnya media sosial, bisa memberikan hasil yang baik dalam budaya politik yang merupakan aspek yang penting dalam sistem politik. Budaya politik sendiri adalah keseluruhan dari pandangan-pandangan politik, seperti norma-norma, pola-pola orientasi terhadap politik dan pandangan hidup umumnya (Atmodjo, 2014).

Media sosial yang mudah diakses sangat gampang mendapat informasi termasuk dunia perpolitikan yang sedang hangat diperbincangkan. Maka dari itu memfilter dulu, dan tidak menelan mentah-mentah informasi yang viral bisa dilakukan untuk mencegah politik kotor yang sering terjadi di Indonesia.

Kemampuan pemilih pemula dalam menentukan pilihan serta mencari informasi dasar dari keputusannya dalam memilih merupakan hal yang tidak mudah dillakukan. Generasi muda yang perlahan mulai tidak apatis dengan pergerakan dan isu pollitik terlihat di media sosial seperti di twitter, Instagram dengan memberikan pendapatkan dan saling bertukar pendapat. Pada titik ini terlihat bahwa generasi muda mulai sadar akan pentingnya partisispasi dalam politik.

Informan dalam peneltian ini berada dalam lingkungan yang tertutup dibatasi penggunaan media sosial, ditambah dengan lingkungan memberikan berbagai isu didalamnya namun siswa tidak bisa mengkonfirmasi hal tersebut keluar atau media informasi di luar sekolah. Hal tersebut menjadikan suatu tantangan tersendiri bagi sentiap individu yang memiliki pandangan yang berbeda dari lingkungannya. Apakah akan mengikuti arus informasi yang terjadi atau memilih untuk mencari kebenaran lain diluar sekolah. Peneliti melihat adanya kesadaran penuh pada informan tentang seberapa pentingnya hak dalam pemilu.

Milenial sebagai generasi muda dan sebagai pemilih pemula merupakan generasi yang menarik untuk dibahas, terutama siswa SMA yang masuk dalam generasi milenial, kebelum mapanan pola fikir dan kedewasaan emosi menjadi faktor psikologi yang dapat mempengaruhi faktor sosiologis. Dalam mendapatkan informasi melalui catatan KOMINFO menjelaskan bahwa Teknologi membuat para generasi internet tersebut mengandalkan media sosial sebagai tempat mendapatkan informasi. Saat ini, media sosial telah menjadi platform pelaporan dan sumber berita utama bagi masyarakat.

Meskipun media sosial menjadi sumber utama tetapi tiga sumber lain seperti, orangtua, teman dan sekolah memiliki pengaruh signifikan. Proses tersebut dinamakan sosialisasi politik yaitu pengalaman yang mempengaruhi tingkah laku politik dikemudian hari yang terjadi sebelumnya dalam kehidupan (Almond, 1984: 325). Penjelasan-penjelasan psikokultural mengenai sosialisasi di awal masa kanakkanak dengan pilihan-pilihan orang tua, menunjukkan bagaimana sosialisasi awal diperkuat oleh teman-teman sebaya di sekolah, dan oleh kelompok-kelompok acuan lain. Pengalaman mengambil tindakan politik, dari hal memberikan suara hingga mencalonkan diri, dibangun di atas pola-pola sosialisasi awal dan memberikan kesempatan untuk proses belajar masyarakat baru. (Apter, 1996: 262).

Oleh karena itu banyak penelitian menyebutkan bahwa pemilih pemula dalam hal ini kaum milenial siswa SMA harus diberikan sosialisasi dari media sosial yang dapat mempengaruhi pilihan mereka atau dalam bahasa lebih lugas dapat mengubah pilihan mereka. Tetapi hal ini tidak sepenuhnya benar karena sebelum kaum milenial ini memiliki persepsi terhadap pilihan mereka terlebih dahulu mereka mendapatkan sosialisasi yang jauh lebih lama dari media sosial yaitu sosialisasi dari keluarga dan teman sebaya. (Turnip, 2016).

Persepsi yang terbangun dalam masyarakat milenial terhadap pilihan politik 


\section{Jurnal Ilmu Pemerintahan: Kajian Ilmu Pemerintahan dan Ilmu Politik, 4 (1), April 2019-59 \\ Mulkanur Rohim ${ }^{*}$ ), Amika Wardana ${ }^{2)}$}

sudah terbangun dari sosialisasi yang terbentuk selama kaum milenial ini tumbuh dan berkembang dengan lingkungan fisik mereka. Sehingga pada dunia maya dalam hal ini adalah media sosial hanya berupa penegasan atau kontradiksi terhadap apa yang sudah mereka dapatkan sebelumnya. Jika ditarik dengan konsep post-truth bahwasannya kaum milenial hanya akan mencari dan mengakses informasi berita pada hal-hal yang sesuai dengan dirinya. Ketika sebuah berita bersebrangan atau tidak sesuai dengan individu tersebut maka akan muncul perdebatan. Bukan hanya di dunia maya tetapi dibawa pada kehidupan sekitar terlebih karena siswa SMA pada teman sebaya mereka.

Siswa-siswa terutama kelas dua belas di Yogyakarta pada umumnya mereka sudah mempunyai persepsi politik karena keluarga yang mensosialisasikannya, hal ini wajar karena siswa SMA adalah individu yang sedang berkembang dan keterlibatan orang tua masih sangat dominan terhadap pilihan politik yang sedang panas pada periode ini. Faktor teman sebaya hanya pada penegasan dan kontradiksi sedangkan media sosial adalah sumber informasi yang dominan meskipun tidak signifikan dalam mempegaruhi persepsi individu tersebut. Hal ini dikarenakan media sosial tersegmentasi antar kubu sehingga terpolarisasi dalam mengikuti akun media sosial para tokoh politik atau yang mendukungnya sudah jelas terekspose. Sementara faktor guru hanyalah sebagai informasi tambahan dalam pembelajaran berlangsung dikarenakan dalam dunia pendidikan guru berlaku netral dihadapan siswa dalam urusan pilihan politik dan sekolah memberikan fasilitas penunjang memperoleh informasi seperti koran atau akses interrnet.

\section{SIMPULAN DAN SARAN}

\section{Simpulan}

Pemilih pemula dengan rentan umur 17-18 tahun cenderung mengalami masa keadaan emosi labil sehingga dapat menyebabkan remaja sulit mendapatkan informasi yang dibutuhkan dengan tepat. Namun pemilih pemula tentu memiliki persepsi, pemikiran, kemauan dan keyakinan terhadap pemilu. Kemampuan pemilih pemula dalam menentukan pilihannya adalah hal yang perlu utuk diapresiasi. Beberapa dari mereka memiliki pemikiran yang diakumulasikan melalui buku bacaan mereka dan bahkan dari teman-teman yang berasal dari kalangan petinggi daerah, hal itu bisa saja terjadi. Sehingga dalam hal ini pemilih pemula adalah individu yang dapat diajak untuk bekerja sama membuat suatu pemikiran besar atau perubahan besar dengan melalui proses alamiah mereka sebagai remaja.

Proses berpikir serta idealisme yang mungkin menjadi alasan kuatnya namun jika diberikan berbagai informasi secara netral, mereka akan dengan antusias mengelola informasi baru tersebut hingga menjadikan proses berpikirnya. Bagi pemilih pemula, pemilu memang memiliki gambaran yang tidak selalu baik, namun mereka paham bagaimana politik tersebut bekerja dan mempengaruhi kehidupan. Sehingga pada perkembangannya pemilih pemula adalah bagian penting dari sebuah pemilihan umum tidak hanya karena suara yang menjadi pertimbangan tetapi juga dapat menjadikan generasi yang memperbaiki politik kearah yang lebih baik .

Analisis politik pada masyarakat milenial, dimana persepsi masyarakat akan terbentuk berdasarkan media yang terus memberitakan tentang kegiatan politik yang terjadi. Khususnya pada siswa SMA dimana mereka adalah pemilih pemula yang berada pada generasi milenial sehingga informasi politik melalui media sosial begitu efektif dalam menyentuh segmentasi masyarakat ini. Siswa SMA di Yogyakarta dalam penelitian ini mempunyai persepi tentang dinamika politik bahwa pilihan politik terbentuk bukan hanya melalui sumber media sosial tetapi orang tua, teman dan sekolah. Media sosial mempunyai peran dalam ketersediaan informasi tetapi 


\section{Jurnal Ilmu Pemerintahan: Kajian Ilmu Pemerintahan dan Ilmu Politik, 4 (1), April 2019- 60}

Mulkanur Rohim ${ }^{*}$ ), Amika Wardana ${ }^{2)}$

pilihan politik sudah tersosialisasikan lebih dalam oleh keluarga ditambah teman dan sekolah sebagai penegas maupun sebagai kontradiksi dalam persepsi yang sudah terbentuk. Penelitian ini memerlukan pendalaman yang lebih lanjut terutama jumlah informan agar dapat digeneralisasikan lebih luas pada masyarakat milenial yang global.

\section{Saran}

Penelitian selanjutnya, harusnya menggunakan data yang lebih besar dan dimungkinkan dengan metode kualitatif dan kuantitatif. Penelitian ini bisa dilakukan secara nasional dengan momentum PEMILU 2019. Harapannya dapat mengetahui persepsi politik pada kaum milenial khususnya siswa SMA yang ada di Indonesia.

Beberapa saran yang dapat dikemukakan adalah sebegai berikut: Pertama, Kurangnya sosialisasi dari KPU untuk pemilih pemula menyebabkan masih banyak pemilih pemula yang belum mendapatkan pendidikan politik secara benar, sebagian besar partisipasi politiknya adalah berdasarkan rekomendasi dari keluarga dan teman sebaya serta pengaruh dari jejaring di media sosial. Kedua, Pemilih pemula sebagai pengguna media sosial yang terbesar di Indonesia berhak mendapatkan pendidikan politik yang dibutuhkan, sehingga mampu menentukan partisipasi politik berdasarkan pertimbangan yang logis, komprehensif dan holistik, meskipun mereka pada dasarnya sudah mengerti gambaran dunia perpolitikan di Indonesia.

\section{DAFTAR PUSTAKA}

Affandi, M. (1971). Himpunan Kuliah Ilmu Ilmu Kenegaraan. Alumni Bandung

Agustino, L., \& Yusoff, M. A. (2010). Politik Lokal di Indonesia: Dari Otokratik ke Reformasi Politik. Jurnal Ilmu Politik, Edisi, 21, 2010.
Alex S. (2006). Semiotika Komunikasi, Bandung: Remaja Rosdakarya

Almond, Gabriel A dan Sidney Verba. (1984). Budaya Politik: Tingkah Laku Politik dan Demokrasi di Lima Negara. Jakarta: Bina Aksara.

Aminah, S. (2006). Politik media, demokrasi dan media politik. Masyarakat, Kebudayaandan.

Aminuddin, M. F., \& Ramadlan, M. F. S. (2015). Match-All party: pragmatisme politik dan munculnya spesies baru partai politik di Indonesia pasca Pemilu 2009. Jurnal Politik, 1(1), 39-74.

Apter, D. E. (1996). Pengantar Analisa Politik. Jakarta: LP3ES.

AZMI, K., \& Astuti, P. (2016). Perilaku Memilih Pemilih Pemula Masyarakat Kendal Pada Pemilihan Umum Presiden dan Wakil Presiden Tahun 2014.Journal of Politic and Government Studies, 5(03), 362370.

Budiardjo, M., Soeseno, N., \& Evaquarta, R. (2014). Pengantar Ilmu Politik.

Bugin B. (2007). Sosiologi Komunikasi Teori, Paradigma, dan Diskursus Teknologi Komunikasi di Masyarakat. Jakarta: kencana Prenada Media Group

Cangara, H. (2007). Pengantar Ilmu Komunikasi Edisi Revisi. Jakarta: PT Raja Grafindo Persada.

Charmaz K., (2000). Grounded Theory: Objectivist and constructivist methods. In N. Denzin, \& Y. Lincoln, (eds.), Handbook of Qualitative Research (pp. 509535). Thousand Oaks, CA, Sage Publications, Inc

Charmaz, K., (2006). Constructing Grounded Theory: A practical guide through qualitative analysis. London: Sage Publications Ltd 


\section{Jurnal Ilmu Pemerintahan: Kajian Ilmu Pemerintahan dan Ilmu Politik, 4 (1), April 2019- 61}

\section{Mulkanur Rohim ${ }^{*}$ ), Amika Wardana ${ }^{2)}$}

Chavez, J. (2012). Fail: The Misuse of Social Media Campaign in the 2012 US Presidential Campaign.

Flora, E. (2014). Analisis framing berita calon presiden RI 2014-2019 pada surat kabar Kaltim Post dan tribun Kaltim. Jurnal Ilmu Komunikasi Universitas Mulawarman, 2(3).

Gurevitch, M., Coleman, S., \& Blumler, J. G. (2009). Political communication-old and new media relationships. The ANNALS of the American Academy of Political and Social Science, 625(1), 164-181.

Hamad, I. (2010). KONSTRUKSI REALITAS POLITIK DALAM MEDIA MASSA (Studi Pesan Politik Dalam Media Cetak Pada Masa Pemilu 1999). Hubs-Asia, 10(1).

Haryanto, H. C., \& Rahmania, T. (2015).

Bagaimanakah

Keterpercayaan

Persepsi terhadap Elit Politik?.Jurnal Psikologi, 42(3), 243-258.

Kantaprawira, R. (2004). Sistem Politik Indonesia, suatu Model Pengantar. Edisi Revisi. Bandung: Sinar Baru Algesindo

Karya, R. C. (2008). Undang-Undang Republik Indonesia Nomor 2 Tahun 2008 Tentang Partai Politik.

Laswell, H. D., Lerner, D., \& Rothwell, C. E. (1952). The Comparative Study of Elites. Stanford: Hoover Institute Studies.

Limilia, P., \& Ariadne, E. (2018). Pengetahuan dan Persepsi Politik pada Remaja. Jurnal Psikologi Sosial, 16(1), 45-55.

Manurung, J. (2017). Persepsi Masyarakat Terhadap Pilkada (Studi Kasus: Masyarakat di Kelurahan Padang Matinggi Kec. Padangsidimpuan Selatan).
Mas'oed, M. (2003). Politik, Birokrasi dan Pembangunan. Yogyakarta: Pustaka Pelajar

Mergel, I. (2010). Gov 2.0 revisited: Social media strategies in the public sector. PA Times/American Society for Public Administration, 33(3), 7-10.

Mochtar M. \& Colin M. A. 2008. Perbandingan Sistem Politik. Yogyakarta: Gajah mada University press.

Mulyana, D. (2013). Ilmu Komunikasi: Suatu Pengantar. Bandung: Remaja Rosdakarya

Nurjaman, A. (2016). Peta Baru Ideologi Partai Politik Indonesia. Jurnal Bestari, (42).

Ohoirat, C. P. (2014). Persepsi Politik Organisasi di Sekolah Tinggi Teologi Sangkakala Salatiga. Magister Manajemen Program Pascasarjana UKSW.

Perangin-angin, L. L., \& Zainal, M. (2018). Partisipasi Politik Pemilih Pemula dalam Bingkai Jejaring Sosial di Media Sosial. Jurnal Aspikom, 3(4), 737-754.

Peraturan Menteri Dalam Negeri Nomor 36 Tahun 2010.

Prasetyoningsih, N. (2014). Dampak Pemilihan Umum serentak bagi pembangunan demokrasi Indonesia. Media Hukum,21(2), 23.

Rahman, M. A. (2015). Kebisaan Pencarian Informasi Murid Sekolah Menengah Atas pada Pemilu Umum di Indoenesia. Record and Library Journal, 2015. 1(2)

Rahmawati, R. (2018). Responsibilitas Penyelenggaraan Pemilu dalam Penanganan Penyelenggaraan Pemilu. Jurnal Politer Prodi Ilmu Politik FISIP UTA'45 Jakarta 3(2)

Riaz, S . (2010). Effect on New Media Technologies on Political Communication. Journal of 


\section{Jurnal Ilmu Pemerintahan: Kajian Ilmu Pemerintahan dan Ilmu Politik, 4 (1), April 2019- 62}

\section{Mulkanur Rohim ${ }^{*}$ ), Amika Wardana ${ }^{2)}$}

Political Studies, Vol 1 (2), 161173

Rivai, A. B. (2016). Politisasi Media di 2014: Aburizal Bakrie dan Segmen Pemilih Pemula. Politik Indonesia: Indonesian Political Science Review, 1(1), 30-44.

Rohmiyati, Y. (2018). Model Perilaku Pencarian Informasi Generasi Milenial. Anuva, 2(4), 387-392.

Romli, L. (2016). Masalah Kelen bagaan Partai Politik di Indonesia PascaOrde Baru.Jurnal Penelitian Politik, 5(1), 21-30.

Sastroadmojo, S. (1995). Partisipasi Politik. Semarang: IKIP Semarang Press.

Shahreza, M. (2017). Komunikator Politik Berdasarkan Teori Generasi. Nyimak (Journal of Communication), 1(1).

Sirozi, M. (2005). Politik pendidikan: Dinamika hubungan antara kepentingan kekuasaan dan praktik penyelenggaraan pendidikan. RajaGrafindo Persada.

Sudibyo, A. (2001). Politik media dan pertarungan wacana: LKIS PELANGI AKSARA.

Sukendar, M.U. (2017). Pemilihan Presiden, Media Sosial Dan Pendidikan Politik Bagi Pemilih Pemula. Jurnal IKON Prodi D3 Komunikasi Massa, 1 (5) 75

Sumartias, S. (2017). Komunikasi Politik Partai Keadilan Sejahtera (PKS) dalam Keterbukaan Ideologi. Jurnal Kajian Komunikasi, 5(1), 43-52.

Survey Nasional CSIS tahun 2017

Syarbani, S. (2002). Sosiologi dan Politik. Bogor: Ghalia Indonesia

Syuhada, K. D. (2018). Etika Media di Era "Post-Truth". Jurnal Komunikasi Indonesia, 75-79.

Turnip, A. D., Suntoro, I., \& Nurmalisa, Y. (2016). Persepsi Masyarakat Terhadap Peranan Partai Politik
Dalam Pemilihan Kepala Daerah. Jurnal Kultur Demokrasi, 4(3).

Tyas, W. S. (2017).Persepsi Pemilih Pemula Pada Iklan Kampanye Politik (Studi Deskriptif Kuantitatif Persepsi Pemilih Pemula Di Kelurahan Karangmalang Pada Iklan Kampanye Politik Bupati Dan Wakil Bupati Kabupaten Sragen Tahun 2015) (Doctoral dissertation, Universitas Muhammadiyah Surakarta).

Wihayati, W. (2016). Persepsi Khalayak Dalam Penggunaan Media Jejaring Sosial Untuk Kampanye Politik. Jurnal Signal, 4(1).

Winarno, B, (2014) Kebijakan Publik: Teori, Proses, dan Studi Kasus; Yogyakarta; Center of Academic Publishing Service (CAPS).

Zainal, Z. (2015). Persepsi Masyarakat terhadap Partai Politik di Desa Terantang Kecamatan Mandastana Kabupaten Barito Kuala. Jurnal Pendidikan Kewarganegaraan, 5(9).

Zamroni. (2000). Paradigma Pendidikan Masa Depan. Yogyakarta: Bigraf Pubilshing

Zuhri, S. (2010). Peranan Sekolah Dalam Proses Sosialisasi Politik (Studi Penelitian Terhadap Siswa SMA Negeri 2 Semarang) (Doctoral dissertation, UNIVERSITAS DIPONEGORO).

\section{Profil Singkat}

Mulkanur Rohim, S.Pd Lahir di Ngawi tanggal 27 April 1994, merupakan mahasiswa program Magister di Pasca Sarjana Universitas Negeri Yogyakarta jurusan Pendidikan IPS. Sebelumnya menempuh sarjana di Universitas Negeri Yogyakarta dengan Jurusan Pendidikan Sosiologi. Saat ini menjadi guru sosiologi di SMAN 1 Kedunggalar sebuah sekolah di Kabupaten Ngawi. Ketertarikan dengan dunia politik dan dunia sosial sudah ada sejak SMA sehingga 
Jurnal Ilmu Pemerintahan: Kajian Ilmu Pemerintahan dan Ilmu Politik, 4 (1), April 2019- 63

Mulkanur Rohim ${ }^{*}$ ), Amika Wardana2)

berlanjut untuk menulis tentang dunia politik, sosial dan pendidikan.

Amika Wardana, S.Sos., MA, Ph.D Lahir di Bantul tanggal 7 November 1980 merupakan Dosen dan Kepala Jurusan Pendidikan IPS Pascasarjana Universitas Negeri Yogyakarta. Pada Jenjang Sarjana
Lulus pada program studi Sosiologi Universitas Gadjah Mada pada tahun 2003 dan melanjutkan Program Master di Univeristy of Nottingham selanjutnya melanjutkan program doktoral di University of Essex dan lulus pada tahun 2013. 